\title{
Педіатрія
}

УДК 616. 61

\author{
®Т. В. Стосва, Г. К. Копійка, С. В. Прохорова
}

Одеський національний медичний університет

\section{НЕФРОПАТІї В ДИТЯЧОМУ ВІЦІ ЯК ФАКТОР РИЗИКУ РОЗВИТКУ АРТЕРІАЛЬНОЇ ГІПЕРТЕНЗІї}

\begin{abstract}
НЕФРОПАТІЇ В ДИТЯЧОМУ ВІЦІ ЯК ФАКТОР РИЗИКУ РОЗВИТКУ АРТЕРІАЛЬНОЇ ГІПЕРТЕНЗІЇ. Артеріальна гіпертенЗія має вагоме значення у структурі серцево-судинних захворювань, які нерідко стають причиною ранньої інвалідизації та смертності. Незважаючи на те, що артеріальна гіпертензія часто дебютує вже у підлітковому віці, їі діагностика не завжди своєчасна, тому що підвищення артеріального тиску ще не має стабільного характеру та не сягає високих показників. Ренокардіальний взаємозв'язок привертає увагу як нефрологів, так і лікарів суміжних спеціальностей: кардіологів, сімейних лікарів, педіатрів. На даний час нефропатії' вважаються незалежними предикторами серцево-судинних захворювань, хоча клінічні симптоми захворювання з'являються лише на пізніх стадіях дисфункції. Отже, пріоритетним є профілактичний напрямок, який передбачає ранню діагностику, бажано ще в період доклінічних проявів захворювання, та своєчасне започаткування коригувальних заходів щодо попередження розвитку ускладнень. У зв'язку із цим, актуальними $€$ пошук ранніх маркерів артеріальної' гіпертензії, виділення у групу ризику контингенту дітей, в яких у подальшому передбачається висока вірогідність розвитку гіпертонічної' хвороби. У роботі наведені результати ретроспективного аналізу медичної' документації (історій хвороб) з метою виділення факторів ризику розвитку нефропатії' в дітей. За допомогою методу факторного аналізу виявлена спільність предикторів розвитку нефропатій та артеріальної гіпертензії. Наявність однакових предикторів та близькі за значенням показники факторного навантаження модифікованих факторів ризику свідчать про необхідність застосування ранніх лікувально-профілактичних заходів щодо попередження виникнення кардіоваскулярної патології в дітей з нефропатіями.
\end{abstract}

НЕФРОПАТИИ В ДЕТСКОМ ВОЗДАСТЕ КАК ФАКТОР РИСКА РАЗВИТИЯ АРТЕРИАЛЬНОЙ ГИПЕРТЕНЗИИ. Артериальная гипертензия имеет значительный вес в структуре сердечно-сосудистых заболеваний, которые нередко становятся причиной ранней инвалидизации и смертности. Несмотря на то, что артериальная гипертензия зачастую дебютирует уже в подростковом возрасте, ее диагностика не всегда своевременна, т.к. исходное повышение артериального давления еще не имеет стабильного характера и не достигает высоких показателей. Ренокардиальные взаимоотношения сегодня привлекают внимание как нефрологов, так и врачей смежных специальностей: кардиологов, семейных врачей, педиатров. В настоящее время нефропатии считаются независимыми предикторами сердечно-сосудистых заболеваний, хотя клинические симптомы заболевания могут появляться и в более отдаленном периоде. Таким образом, приоритетным является профилактическое направление, предусматривающее раннюю диагностику, желательно еще в период доклинических проявлений заболевания, и своевременное начало корригирующих мероприятий по предупреждению развития осложнений. В связи с этим, актуальными являются поиск ранних маркеров артериальной гипертензии, выделение в группу риска контингента детей, у которых в дальнейшем высока вероятность развития гипертонической болезни. В работе приведены результаты ретроспективного анализа медицинской документации (историй болезней) с целью выделения факторов риска развития нефропатии у детей. С помощью метода факторного анализа выявлена общность предикторов развития нефропатий и артериальной гипертензии. Наличие одинаковых предикторов и близкие по значению показатели факторной нагрузки модифицируемых факторов риска свидетельствуют о необходимости применения ранних лечебно-профилактических мероприятий по предотвращению возникновения кардиоваскулярной патологии у детей с нефропатиями.

NEPHROPATHY IN CHILDHOOD AS A RISK FACTOR FOR HYPERTENSION. Arterial hypertension is the most common cause of cardio - vascular diseases, which later often leads to early disability and mortality. Often hypertension debuts at a teenager, but it is so difficult to diagnose it in children, because high blood pressure has not yet have a stable nature and does not reach high numbers. Communication cardiac and renal disease has attracted the attention of both nephrologists and physicians: cardiologists, family physicians, pediatricians. Currently nephropathy is an independent predictor of cardio - vascular disease. However, clinical symptoms occur only at later stages of the dysfunction. Thus, the primary task of preventive medicine is early diagnostics, preferably in the phase of preclinical manifestations of the disease, which further contributes to the timely initiation of treatment, prevention of complications. Topical is the finding early markers of arterial hypertension, the selection among children whose, who in the future will most likely get hypertension. The article presents the results of a retrospective analysis of medical records of children with nephropathy. The method of factor analysis revealed a close relationship in the development of renal disease and cardio - vascular system. The generality of controllable risk factors in the development of pathology cardio - vascular and renal disease should be considered at the stage of preventive measures for the prevention of disease through active influence on the factors detected at the stage of pre-clinical manifestations.

Ключові слова: артеріальна гіпертензія, нефропатія, фактори ризику, серцево-судинна система.

Ключевые слова: артериальная гипертензия, нефропатия, факторы риска, сердечно-сосудистая система.

Key words: hypertension, nephropathy, riskfactors, cardio-vascular system. 
ВСТУП. Взаємозв'язок кардіальної та нефрологічної патологій, коли патофізіологічні порушення в одному органі можуть призводити до дисфункції іншого, вивчаютьлікарі суміжнихспеціальностей: нефрологи, кардіологи, сімейні лікарі, педіатри. Без сумніву, будь-яке ушкодження нирки, як гостре, так і хронічне, асоціюється $з$ високим ступенем ризику розвитку серцево-судинної патології. На сьогодні найбільш частою причиною виникнення серцево-судинних катастроф, інвалідності та смертності, згідно з даними загальносвітової медико-соціальної статистики, є артеріальна гіпертензія [1-3]. Насторожують факт омолодження даної патології, її висока частота в підлітків [1]. Доводиться констатувати, що нерідко підвищення артеріального тиску в підлітковому віці розглядається лише як прояв вегетосудинної дисфункції та недооцінюється лікарями. Слід також відмітити, що артеріальну гіпертензію відносно легко виявити у дорослій популяції та досить непросто діагностувати в дітей, особливо на ранніх стадіях її розвитку, коли підвищення артеріального тиску ще не має стабільного характеру та не сягає високих показників. У зв'язку з цим, витоки артеріальної гіпертензії слід шукати вже у дитячому та підлітковому віці, тобто на ранніх етапах її становлення, а не на стадії стабілізації патології та органних змін у дорослих [2, 3]. У сучасній медицині для дорослих хворих терапевтичного профілю передбачена стратегія профілактики захворювань серцево-судинної системи, в основу якої покладена концепція факторів ризику серцево-судинних захворювань, підтверджена мультицентровими епідеміологічними та клінічними дослідженнями (Р. Г. Оганов, 2001; М. Г. Глезер та ін., 2002). Водночас у педіатричній практиці концепція факторів ризику щодо розвитку артеріальної гіпертензії не знайшла широкого застосування: дітей, підлітків та осіб молодого віку до останнього часу традиційно відносили до групи низького ризику (Е. В. Ощепкова, 2002; Ю. І. Ровда та ін., 2004). Тому численні аспекти впливу факторів ризику на розвиток артеріальної гіпертензії в дітей та підлітків усе ще залишаються недостатньо вивченими. 3 урахуванням імовірності розвитку артеріальної гіпертензії на тлі нефропатії [3, 4] в даному дослідженні проводився аналіз факторів ризику розвитку найбільш розповсюджених у педіатричній практиці захворювань нирок - нефропатій мікробно-запального та дисметаболічного генезу.

Мета дослідження - виявити ранні маркери розвитку нефропатій у дітей за допомогою методу факторного аналізу та проаналізувати їх значущість у розвитку патології нирок та серцево-судинних захворювань, зокрема артеріальної гіпертензії.

МАТЕРІАЛИ ТА МЕТОДИ. В роботі проведено ретроспективний аналіз медичної документації (600 історій хвороб дітей з нефропатіями: 300 дітей з нефропатіями мікробно-запального характеру та 300 дітей $з$ нефропатіями дисметаболічного генезу). За допомогою факторного аналізу [5] було визначено найбільш значущі фактори ризику розвитку нефропатій. У ході дослідження виділено фактори першого (Ф1), другого (Ф2) та третього (Ф3) роду, які скла- дались 3 комбінації найбільш сильно пов'язаних між собою первинних ознак (табл. 1). Значущість ознак оцінювали за рівнем факторного навантаження. Так, при високому $(>0,7)$ та середньому $(>0,5)$ факторному навантаженні ознаки, що досліджувались, визначали вірогідність розвитку нефропатій у дітей.

Отримані результати також були статистично проаналізовані 3 використанням методів параметричної та непараметричної статистики в програмному пакеті STATISTICA 6.

РЕЗУЛЬТАТИ ДОСЛІДЖЕННЯ ТАЇХ ОБГОВОРЕННЯ. Враховуючи мету дослідження, був проведений порівняльний аналіз виділених факторів ризику розвитку нефропатій у дітей та факторів ризику розвитку артеріальної гіпертензії.

При вивченні впливу факторів ризику на розвиток нефропатії методом факторного аналізу враховувалась значна кількість різноманітних параметрів, серед яких були виділені найбільш значущі та встановлені взаємозв'язки між ними (спадковість, шкідливі звички, особливості конституції та способу життя, наявність супутньої соматичної патології, особливості перебігу вагітності та перинатального періоду).

Як видно з таблиці 1, до факторів першого роду щодо розвитку нефропатій належать такі несприятливі ознаки, як нефропатія та артеріальна гіпертензія під час вагітності. Характерним $є$ обтяжений спадковий анамнез по материнській лінії, а саме гіпертонічна та сечокам'яна хвороби, по батьківській лінії наявність гіпертонічної хвороби і захворювань шлунково-кишкового тракту.

До факторів другого роду належить комбінація таких несприятливих ознак, як: куріння батька та матері, передчасні пологи, токсикоз під час другої половини вагітності.

До факторів третього роду належить найбільша кількість несприятливих компонентів, які складаються як із родинних ознак, так і з індивідуальних особливостей дитини. Так, з боку матері найвагомішими були загроза переривання вагітності, спадковість (мікробно-запальні захворювання), надмірна маса. 3 боку батька - малорухомий спосіб життя. 3 боку дитини значущими ознаками були перенесена гіпоксично-ішемічна енцефалопатія в анамнезі, раннє штучне вигодовування на першому році життя, надмірна маса, малорухомий спосіб життя, пасивне куріння, часті повторні епізоди гострих респіраторних захворювань в анамнезі, супутня патологія ЛОР-органів.

Потрібно відмітити, що факторні навантаження являють собою коефіцієнти кореляції фактора з усіма показниками, які були використані в дослідженні.

Таким чином, усі ознаки, з яких складаються фактори першого, другого та третього роду, формують складні причинно-наслідкові зв'язки, що, врештірешт, можуть призводити до розвитку ниркової патології. При цьому, якщо в дитини несприятливі ознаки зустрічаються не ізольовано, а у виділених комбінаціях, то ризик розвитку захворювання збільшується. Важливо підкреслити, що врахування таких комбінацій, а не розрізнених поодиноких ознак, дозволяє підвищити ефективність прогнозування розвитку захворювання. 


\section{Педіатрія}

Таблиця 1. Факторні навантаження основних значущих предикторів, які визначають розвиток нефропатій у дітей

\begin{tabular}{|c|c|c|c|}
\hline Значуща ознака & $\Phi 1$ & $\Phi 2$ & Ф3 \\
\hline Захворювання нирок у матері під час вагітності & 0,50 & 0,16 & 0,12 \\
\hline Артеріальна гіпертензія в матері під час вагітності & 0,59 & 0,016 & 0,05 \\
\hline Токсикоз під час вагітності & 0,07 & 0,56 & 0,13 \\
\hline Загроза переривання вагітності & 0,07 & 0,15 & 0,53 \\
\hline Спадковість (материнська лінія - пієлонефрит) & 0,33 & $-0,11$ & 0,51 \\
\hline Спадковість (материнська лінія - сечокам'яна хвороба) & 0,52 & 0,24 & 0,28 \\
\hline Спадковість (батьківська лінія - жовчнокам'яна хвороба) & 0,61 & $-0,04$ & 0,06 \\
\hline Куріння батька & 0,04 & $-0,62$ & 0,27 \\
\hline Перенесена гіпоксично-ішемічна енцефалопатія & 0,10 & 0,16 & 0,53 \\
\hline Надлишкова маса матері & $-0,24$ & 0,03 & 0,67 \\
\hline Куріння матері & 0,0002 & 0,58 & 0,12 \\
\hline Передчасні пологи & $-0,14$ & 0,53 & 0,23 \\
\hline Малорухомий спосіб життя батька & 0,13 & 0,13 & 0,52 \\
\hline Пасивне куріння дитини & 0,24 & $-0,03$ & 0,58 \\
\hline Надлишкова маса дитини & $-0,10$ & $-0,16$ & 0,54 \\
\hline Малорухомий спосіб життя дитини & 0,08 & 0,06 & 0,77 \\
\hline Спадковість (батьківська лінія - гіпертонічна хвороба) & 0,56 & 0,26 & 0,19 \\
\hline Раннє штучне вигодовування дитини & 0,03 & 0,24 & 0,77 \\
\hline Часті епізоди ГРВІ & 0,22 & 0,26 & 0,51 \\
\hline Супутня хронічна ЛОР-патологія в дитини & 0,21 & 0,24 & 0,52 \\
\hline Спадковість (материнська лінія - гіпертонічна хвороба) & 0,53 & 0,26 & 0,1 \\
\hline
\end{tabular}

В процесі аналізу особливу увагу приділяли вивченню факторів ризику, які визнано предикторами розвитку артеріальної гіпертензії.

За даними численних клінічних та епідеміологічних досліджень (С. А. Дмитренко, 1999; В. І. Маколкин, В. І. Подзолков, 1999; Н. І. Яблучанський та ін., 2004), одним 3 найбільш важливих факторів, що сприяють виникненню та прогресуванню артеріальної гіпертензії в підлітків, є обтяжена спадковість за серцево-судинними захворюваннями. У нашому дослідженні серед родичів першого ступеня споріднення такий зв'язок відмічався у $36 \% \pm 1,8 \%$ пробандів. При цьому продемонстрована перевага спадкової обтяженості саме по материнській лінії. Звертає на себе увагу також висока частота патологічного перебігу вагітності, в тому числі наявність артеріальної гіпертензії, гестаційної нефропатії, які було виявлено у $57 \% \pm 2,1 \%$ досліджуваних.

Відмічається пряма та стійка кореляція між масою тіла та рівнем артеріальної гіпертензії. Так, надлишкова маса асоціюється з 2-6-кратним підвищенням ризику виникнення артеріальної гіпертензії [6]. У групі обстежених дітей надлишкова маса була виявлена у $12 \% \pm 0,8 \%$ випадків.

У людей, які ведуть малорухомий спосіб життя, ризик виникнення артеріальної гіпертензії на 20$50 \%$ вищий, ніж у фізично активних [6]. Залежність між ожирінням та артеріальною гіпертензією була до- кументально підтверджена у Фрамінгемському дослідженні (Framingham Heart Study) [7]. За результатами проведеного аналізу, гіподинамія в дітей спостерігалась у $49 \% \pm 2,2 \%$ випадків.

Загальновідомий негативний вплив куріння на розвиток серцево-судинної патології. Доведено, що нікотин різко підвищує артеріальний тиск у курців. Ефект кожної цигарки триває близько 30 хв. Уже на 1-й хвилині систолічний артеріальний тиск підвищується на 15 мм рт. ст. У групі дітей від 12 до 18 років з ризиком розвитку нефропатії курили $21 \% \pm 2,3 \%$.

Отримані результати свідчать про те, що патологія сечовивідної та серцево-судинної систем має загальні фактори ризику, серед яких визначено такі, як обтяжена спадковість, зайва маса батьків та дитини, активне куріння батьків, активне та пасивне куріння дитини, малорухомий спосіб життя.

ВИСНОВКИ. У ході дослідження методом факторного аналізу визначено фактори ризику розвитку нефропатій у дітей. Продемонстровано спільність виявлених факторів ризику в розвитку патології серцево-судинної системи та патології нирок.

ПЕРСПЕКТИВИ ПОДАЛЬШИХ ДОСЛІДЖЕНЬ. Результати роботи свідчать про те, що активне вивчення та усунення модифікованих факторів ризику на етапі доклінічних проявів дозволять попередити розвиток і прогресування кардіоренальної патології. 


\section{Педіатрія}

СПИСОК ЛІТЕРАТУРИ

1. Артеріальна гіпертензія у дітей та підлітків / М. В. Хайтович, О. О. Гордон, Р. В. Терлецький [та ін.] // Педіатрія, акушерство і гінекологія. - 2006. - № 2. C. 28-37.

2. Громнацька Н. М. Вплив показників маси тіла на частоту і характер перебігу артеріальної гіпертензії у дітей і підлітків / Н.М.Громнацька // Буковинський медичний вісник. - 2007. - Т. 11, № 2. - С. 34-36.

3. Доскин В. А. Многофакторная оценка состояния здоровья детей раннего возраста / В. А. Доскин, 3. С. Макарова // Российский вестник перинатологии и педиатрии. - 2006. - № 6. - С. 30-37.

4. Игнатова М. С. Нефропатии у детей: профилактика нефропатий и предупреждение прогрессиро- вания болезней почек у детей / М. С. Игнатова // Российский ветсник перинатологии и педиатрии. 2005. - № 6. - С. 3-7.

5. Реброва О. Статистический анализ медицинских данных / О. Реброва. - М. : Медиа Сфера, 2006. - 305 c.

6. Bloodpressure and adiposity in children and adolescents / G. Paradis, M. Lambert, J. O'Loughlim [et al.] // Circulation. - 2004. - Vol. 110. - P. 1832 1838.

7. Ожирение и артериальная гипертония / Е. Н. Синицина, В. Б. Марковский, А. С. Галанова [и др.] // Лечащий врач. - 2008. - № 4. - С. 14-17. 